\title{
Transverse trabeculae and osteoporosis in bones in experimental protein-calorie deficiency
}

\author{
By B. S. PLATT AND R. J. C. STEWART \\ Human Nutrition Research Unit, Nutrition Building, National Institute for \\ Medical Research, Mill Hill, London, N.W.7
}

(Received 20 November 1961-Revised 26 February 1962)

Multiple transverse trabeculae which could not be related to any infective process were recently found in radiographs of the bones of pigs maintained on low-protein diets (Stewart \& Platt, I 958); it was suggested that they were evidence of disturbances in the balance between chondrogenic and osteogenic activity. The occurrence of transverse bands of dense tissue in bone has been recognized for many decades-even before the introduction of radiology, and in 1923 Harris (1924-5) drew attention to the transverse lines seen in radiographs of the growing ends of the long bones of children. The conclusion reached from subsequent investigations (Harris, 1926; Eliot, Souther \& Park, 1927; Harris, I93 I $a, b$; Sontag, 1938; Sontag \& Harris, I938; Follis \& Park, I952; Dreizen, Currie, Gilley \& Spies, 1956) is that, though such lines are common in the bones of malnourished children, they are also found in the bones of those without obvious signs of malnutrition, and can often be related to some illness such as measles or whooping cough. Changes in bone are shown in this paper to be associated with protein-calorie deficiency.

The term protein-calorie deficiency has recently been proposed as the name for a class of diseases which includes marasmus, marasmic kwashiorkor and kwashiorkor, diseases which are also known by numerous other names. This proposal was made in the course of a revision of the international classification of nutritional diseases 'in keeping with the advances and understanding of those conditions' (Joint FAO/WHO Expert Committee on Nutrition, 1962). The hyphen in the expression protein-calorie deficiency is intended to indicate that the two dietary factors are always interrelated; this is true for the proportion of protein to the calorie content of a diet; also the protein value for the consumer of a given diet varies with the energy content of the food eaten in relation to the consumer's caloric needs (Platt, Miller \& Payne, I96I). The protein value of a diet to the consumer is reduced proportionately much more than the extent of the caloric restriction. In assessing the caloric needs of a growing animal from its weight, consideration should be given to the effects of previous malnutrition. Thus in making adjustments for body size in cases of 'emaciation resulting from prolonged undernutrition, the actual body-weight should be ignored and a "target" or desired body-weight should be used instead' (FAO, 1957).

In our experiments, diets and dietary regimens have been devised on which the pig develops disorders closely resembling those found at the two ends of the spectrum of protein-calorie deficiency disease in human subjects-marasmus and kwashiorkor. 
Recently McCance, Ford \& Brown (I96I) have described in the bones and teeth of pigs abnormalities resembling those we have observed, but they gave their animals a good diet in very small quantities-at most only about one-fifth of the least amounts we gave to our animals at corresponding weights and ages. Such severe undernutrition for relatively long periods is not as widespread in the human infant as is the degree of protein-calorie deficiency developed in our animals. We submit therefore that the evidence presented in this paper will be of immediate value in the understanding of the changes in the bones, notably the transverse trabeculation so often seen in children

\section{EXPERIMENTAL}

\section{Animals and diets}

Piglets on removal from the sow at 5 days of age were given a commercial weaning diet (Amvilac no. I, Glaxo Laboratories Ltd) for about 2 weeks, until they reached a weight of $3 \mathrm{~kg}$, when they were transferred gradually to the experimental diets. During the 2-week period each received an injection of $2 \mathrm{ml}$ of an iron dextran preparation (Imferon, Benger Laboratories Ltd) containing $5^{\circ} \mathrm{mg}$ iron $/ \mathrm{ml}$ and, to control scouring, a course of Stromez (Imperial Chemical Industries Ltd) (sulphadimidine ro $\%$, streptomycin sulphate $2 \%$, light kaolin $86 \%$ ). They were housed indoors in individual pens with wire-mesh floors.

The diets used were low-protein (LP), LP supplemented with carbohydrate $(\mathrm{LP}+\mathrm{CH}), \mathrm{LP}$ in which casein $(5$ and $20 \%, \mathrm{w} / \mathrm{w})$ replaced starch $(5 \mathrm{CLP}$ and $20 \mathrm{CLP}$ ), and $\mathrm{LP}, \mathrm{LP}+\mathrm{CH}$ and 5 CLP diets supplemented with a mixture of vitamins and $\mathrm{CaCO}_{3}(\mathrm{LP}+\mathrm{V}, \mathrm{LP}+\mathrm{CH}+\mathrm{V}$ and $5 \mathrm{CLP}+\mathrm{V})$. The control animals were fed ad lib. on N1, a commercial diet (Amvilac no. 2, E. E. Chaney and Sons Ltd, Uxbridge). The composition of the various experimental diets is shown in Table I.

The daily intakes of protein, carbohydrate, vitamins, carotenoids, calcium and phosphorus are shown in Table 2. Towards the end of the experiment the food consumption of some animals, especially those in the LP $+\mathrm{CH}$ group, fell below the amounts shown, and the carbohydrate supplements were then usually withdrawn. When it was desired to increase the protein intake, isocaloric amounts of 20 CLP or ${ }_{5} \mathrm{CLP}$ diets were substituted for the $\mathrm{LP}$ and $\mathrm{LP}+\mathrm{CH}$ diets, or the $\mathrm{N} 1$ diet was given ad lib.

\section{Methods}

Radiographs were taken on non-screen film (Ilfex, Ilford Ltd) with a Solus Eureka tube, $\mathrm{r} \cdot 8 \mathrm{~mm}$ focus, and a tube-to-film distance of ${ }_{3} 6$ in. to reduce errors due to parallax. Exposures ranged from 0.15 to $0.25 \mathrm{sec}$ at $50 \mathrm{kV}$ and $30 \mathrm{~mA}$, but were always the same for animals of the same age. No anaesthetic was used. Measurements of bone length were obtained from the radiographs.

At death, longitudinal slices, $3 \mathrm{~mm}$ thick, were cut from the growing ends of the long bones and fixed by immersion in Wittmaak's (I9I I) solution for $48 \mathrm{~h}$, Orth's (I896) fluid for a further $48 \mathrm{~h}$ and then $4 \%(\mathrm{v} / \mathrm{v})$ formaldehyde for at least $\mathrm{r} 4$ days. The slices were decalcified in I \% (v/v) nitric acid, dehydrated in alcohol ( 74 over- 
proof spirit), cleared in carbon disulphide + chloroform followed by pure carbon disulphide, and embedded in paraffin wax. Sections Io $\mu$ thick were cut, stained with Delafield's or Ehrlich's haematoxylin, Biebrich's scarlet and eosin.

\section{Table I. Percentage composition of basal diets and dietary supplements given to the pigs}

Diet

Ingredient

$\overbrace{\mathrm{LP}}^{\mathrm{LP}+\mathrm{CH}} \quad \mathrm{LP}+\mathrm{V} \quad \mathrm{LP}_{\mathrm{C}} \mathrm{CH}+\mathrm{V} \quad{ }_{5} \mathrm{CLP} \quad{ }_{5} \mathrm{CLP}+\mathrm{V} \quad 20 \mathrm{CLP}$

Whole-wheat four

Cooked haricot

beans

Lucerne meal

de Loureiro's (I93I)

salt mixture

Chromic oxide

Arachis oil + ergo-

calciferol (50 i.u./g)

Maize starch

Casein

Vitamin supplement*

Carbohydrate sup-

plement†

$\left.\begin{array}{c}30 \\ 2 \\ 3 \\ 4 \\ 0 \cdot 3 \\ 2 \cdot 0\end{array}\right\}$

As for LP

* Contained (per roo g diet) thiamine hydrochloride $0.22 \mathrm{mg}$, riboflavin $0.33 \mathrm{mg}$, calcium pantothenate $2.22 \mathrm{mg}$, nicotinic acid $3.33 \mathrm{mg}$, pyridoxine hydrochloride $0.55 \mathrm{mg}$, choline hydrochloride roo. $0 \mathrm{mg}$, cyanocobalamin $2.2 \mu \mathrm{g}$. Additional calcium $\left(0.26 \mathrm{~g} / 100 \mathrm{~g}\right.$ diet, i.e. $0.65 \mathrm{~g}$ daily) as $\mathrm{CaCO}_{3}$ was also given with the vitamin supplement.

+ Comprised maize starch $24.7 \%$, glucose $75 \%$ and chromic oxide $0.3 \%$ and was given separately, between meals of the basal diet, at the rate of $100 \mathrm{~g}$ for each $250 \mathrm{~g}$ of basal diet.

Table 2. Protein, carotenoids, calcium and phosphorus in the daily diets of the experimental pigs

\begin{tabular}{|c|c|c|c|c|}
\hline & \multicolumn{4}{|c|}{ Diet } \\
\hline & $\begin{array}{c}\mathrm{LP} \\
\text { (and LP+V) }\end{array}$ & $\begin{array}{c}\mathbf{L P}+\mathrm{CH} \\
\text { (and } \mathbf{L P}+\mathrm{CH}+\mathrm{V} \text { ) }\end{array}$ & $\begin{array}{c}5 \text { CLP } \\
\text { (and } 5 \text { CLP }+V \text { ) }\end{array}$ & $20 \mathrm{CLP}$ \\
\hline Food offered (g): & & & & \\
\hline Basal diet* & $250 \dagger$ & 250 & 250 & 250 \\
\hline $\begin{array}{l}\text { Carbohydrate } \\
\text { supplement* }\end{array}$ & - & 100 & - & - \\
\hline Protein (g) & 15 & I 5 & $26 \cdot 5$ & $63 \cdot 2$ \\
\hline ND-p Cals \% † & 3.5 & $2 \cdot 5$ & 6.6 & $8 \cdot 3$ \\
\hline Carotenoids $(\mu \mathrm{g}) \S$ & 2400 & 2400 & 2400 & 2400 \\
\hline $\mathrm{Ca}(\mathrm{mg}) \|$ & $\begin{array}{c}1186 \\
(1836)\end{array}$ & $\begin{array}{l}\text { I } 188 \\
(1838)\end{array}$ & $\begin{array}{c}1206 \\
(1856)\end{array}$ & $\mathrm{r} 266$ \\
\hline $\mathrm{P}(\mathrm{mg})$ & 1150 & 1160 & 1250 & 1550 \\
\hline
\end{tabular}

* See Table r.

+ With the exception of pigs nos. $32,37,42,45$ and 50 , which received only $180 \mathrm{~g}$.

$\mp$ Values were determined by assays on rats (Platt \& Miller, 1959); lower protein values will be obtained for the same diets if the amounts eaten are insufficient to meet the consumer's energy needs.

$\S$ Lucerne meal supplying $2400 \mu \mathrm{g}$ carotenoids as mixed xanthophyll and carotene would supply about $800 \mu \mathrm{g}$ carotene/day, which is adequate for the pig (Braude, Foot, Henry, Kon, Thompson \& Mead, I94I).

I| Does not include any $\mathrm{Ca}$ obtained from the drinking water which might have supplied between 5o and $80 \mathrm{mg} / \mathrm{pig}$ daily. The vitamin supplement contained $\mathrm{CaCO}_{3}$ and the $\mathrm{Ca}$ intakes of animals receiving the supplement are shown in parentheses. 
The ratio $A: R$ was used as an index of bone calcification; $A$ is the weight of the ash of the bone and $R$ that of the dry fat-free bone minus the ash (Chick \& Roscoe 1926; Chick, Korenchevsky \& Roscoe, 1926).

\section{RESULTS}

\section{Growth of long bones}

When animals are fed on a low-protein diet, the rate of development is slow and the increase in bone length in a given period may be only one-third that in animals receiving a normal diet (Stewart \& Platt, 1958).

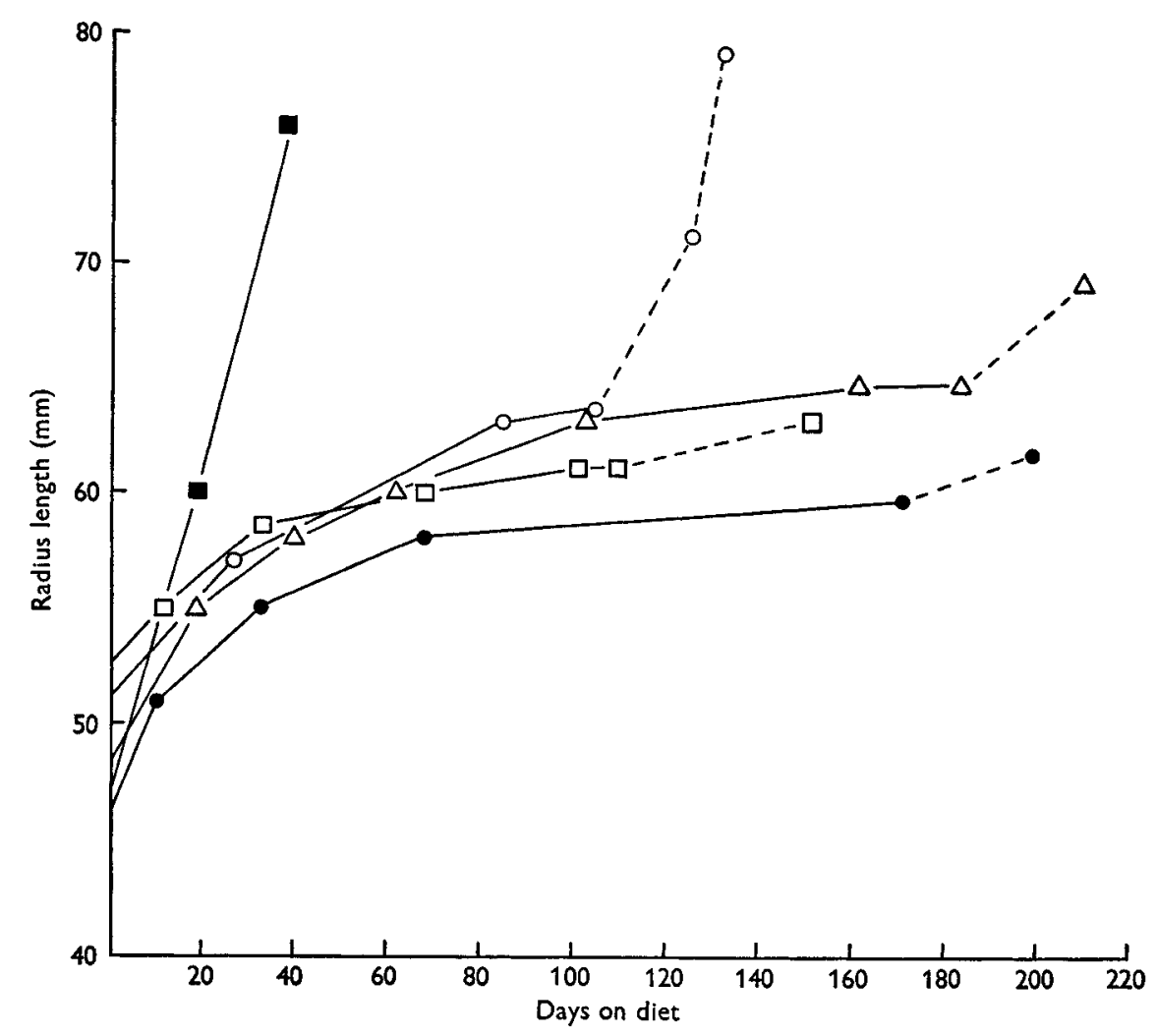

Fig. I. Increase in rate of linear growth of the radii of pigs when diets containing a higher protein content are substituted for the $\mathrm{LP}$ or $\mathrm{LP}+\mathrm{CH}$ diets. - - , indicates period on original diet; - - . -, indicates period on improved diet; $\square-\square$, pig no. 45, LP diet changed to 5 CLP; $\bullet-$ pig no. 37 , LP diet changed to 5 CLP; $\bigcirc-0$, pig no. 82, LP + CH diet changed to N1 ad lib.; $\Delta-\Delta$, pig no. 75, LP+CH diet changed to $20 \mathrm{CLP} ;-\rightarrow$ pig no. $4 \mathrm{x}, \mathrm{Nl}$ diet (included to show normal growth of pig bone).

Table 3 shows the increases in the length of the radii of pigs on the different experimental diets. Thus, the radius of the animal on LP diet (pig no. 77, litter $F$ ) increased by $20 \mathrm{~mm}$ in the 16 weeks of the experiment; with isocaloric quantities of the 5 CLP diet (pig no. 76) the radius lengthened by $30 \mathrm{~mm}$, whereas the bone of the pig (no. 75) on the $\mathrm{LP}+\mathrm{CH}$ diet only grew $15 \mathrm{~mm}$. This sort of observation has been made 
Vol. 16

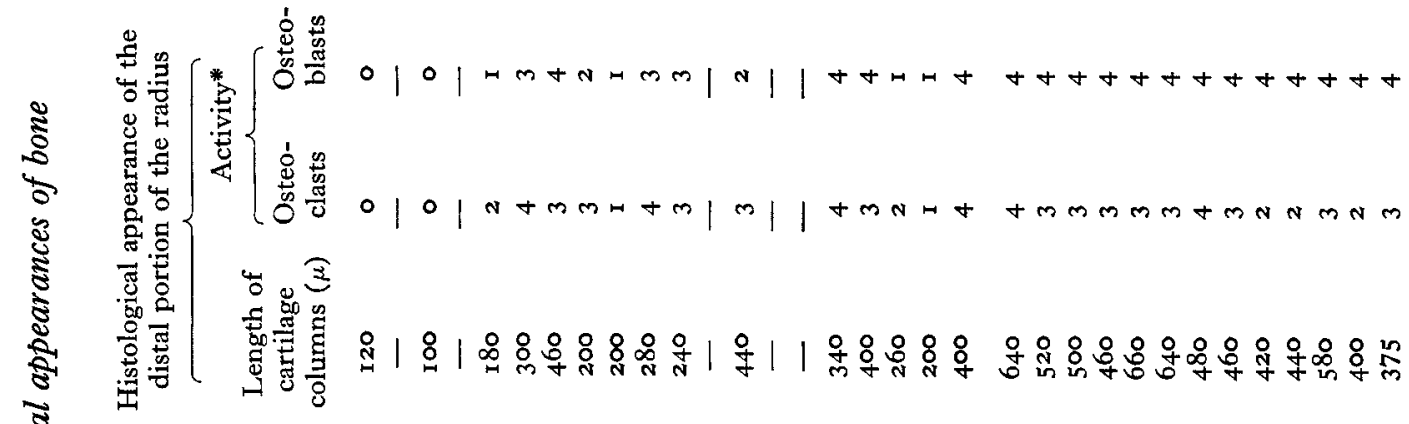

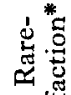

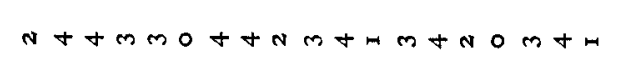

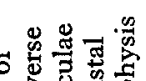

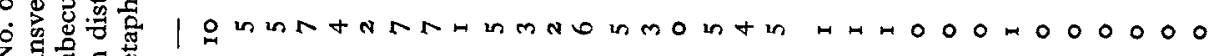
氖馬.

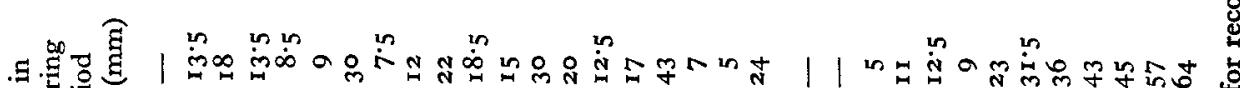

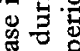

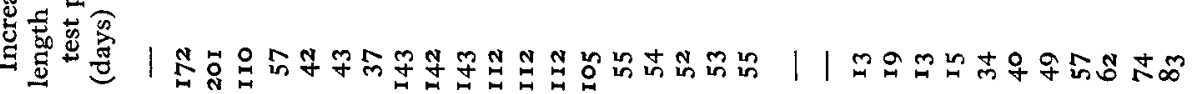

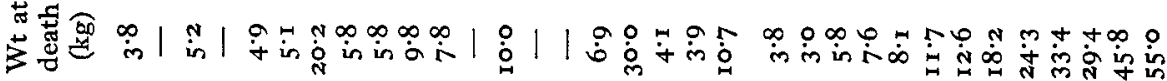

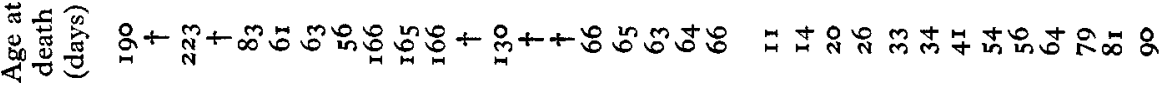

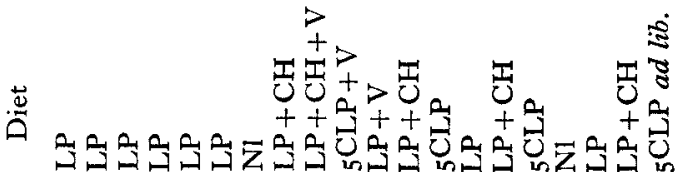

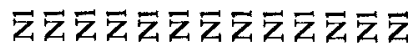

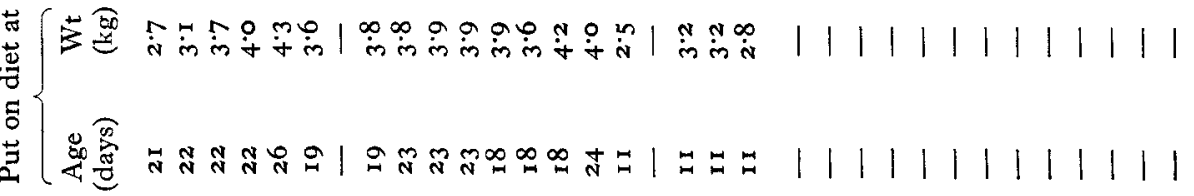
莺

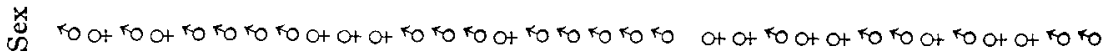

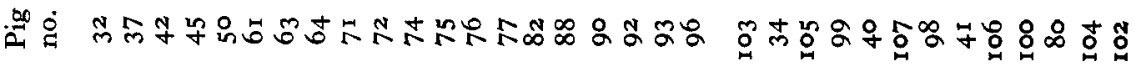


repeatedly and, though the increase in bone length of the animals on the $\mathrm{LP}+\mathrm{CH}$ diet was not always less than that of all pigs on the LP diet, it was invariably less than that of their own litter-mates receiving the LP diet (Table 3).

None of the bones of animals on the deficient diets increased in length as rapidly as those of the normal pigs; the radius of pig no. 96 given the ${ }_{5}$ CLP diet ad lib., although increasing in length more rapidly than that of pig no. 88 given restricted amounts of 5 CLP, did not grow as fast as that of a normally fed animal. Differences were also found in the thickness of the epiphysial cartilages, those of the proteincalorie deficient animals, and more especially those of the animals on the $\mathrm{LP}+\mathrm{CH}$ diets, being thinner than those of the animals maintained on the 5 CLP or Nl diets (Pl. I).

The improvement in bone length brought about by replacing part of the carbohydrate in the LP diet by an equal weight of protein (casein) was demonstrated in protein-calorie deficient animals. Fig. I shows the increase in the rate of linear bone growth produced by increased protein intake after the pigs had been on diets $\mathrm{LP}+\mathrm{CH}$ (pigs nos. 82 and 75) and LP (pigs nos. 37 and 45) for 105, I84, I72 and I Io days, respectively. In the second stage of the experiment pig no. 82 received the $\mathrm{Nl}$ diet ad lib. for 4 weeks, and growth during this period was the same as that of the control at an earlier age; the other animals received the 20 CLP (pig no. 75) and 5 CLP (pigs nos. 37 and 45 ) diets in quantities isocaloric with the previous rations of LP diets, and improvement was less marked.

\section{Radiographic structure of long bones}

Radiographs taken when the piglets arrived at the laboratory occasionally showed a single transverse trabecula or 'birthline'; a second such structure often developed coincident with the removal of the piglet from the sow and its transfer to the artificial (commercial weaning) diet. These structures were transient, being quickly reorganized within the metaphysis.

In the long bones of the protein-calorie deficient pigs both rarefaction and transverse trabeculation ( $\mathrm{Pl} .2 b, c, d)$ were evident and as many as ten trabeculae have been seen in the distal metaphysis of the radius (Table 3 ). Pig no. 77 (Pl. $2 b$ ) received the LP diet, pig no. 76 (Pl. 2a) the 5 CLP and pig no. 74 (Pl. 2c) the LP diet supplemented with $65^{\circ} \mathrm{mg}$ daily of calcium as $\mathrm{CaCO}_{3}$, as well as with $\mathrm{B}$ vitamins. All the diets were given in isocaloric amounts. The radius of animal no. 76 , having the increased proportion of protein in the diet, was more heavily mineralized than that of pig no. 77 on the LP diet, and there was also a reduction in the number and prominence of the transverse trabeculae (Pl. $2 a, b$ ). On the other hand, no improvement of the radius occurred when extra calcium and B vitamins were given (cf. pigs nos. 74 and 77 , Pl. $2 b, c)$. Rarefaction of bone accompanying the administration of the low-proteir diets was seen in litter $H$ (Table 3). The addition of extra carbohydrate (pig no. 93 . to the LP diet resulted in the production of a smaller bone containing a smaller quantity of calcified tissue (Table 4) than that found in the animal without the extra carbohydrate, although the protein and calcium intakes of the two animals were the same. 


\section{Microscopic appearance of long bones}

Sections of the long bones of pigs maintained on diets containing low concentrations of protein ( $5 \mathrm{CLP}, \mathrm{LP}$ and $\mathrm{LP}+\mathrm{CH}$ ) showed changes which varied in degree but not in type (Stewart \& Platt, 196r). The most consistent and prominent changes were in the zones of proliferating and maturing cartilage, which were often only about half or less than half of the thickness of the normal (P1. I $a-d$; pigs nos. 90, 88, 92, and 93), and in severe cases the zone of maturing cartilage was sometimes absent.

Animal no. 88 received the 5 CLP diet in quantities isocaloric with the LP diet of pig no. 92 and its bones (Pl. I $b$ ), though definitely not normal (cf. pig no. 9o, Pl. $\mathrm{x} a$ ), were much less abnormal than those of the animal on the LP diet (pig no. 92). Pig no. 93 receiving additional carbohydrate was more severely affected than pig no. 92 , though the bones of both animals showed reduced growth of cartilage. Fully 'hypertrophied' cartilage cells were rare and small compared with the mature cells of normal cartilage; the matrix occupied a proportionately greater area and the calcified cartilaginous trabeculae of the primary spongiosa were thickened. The thickening was also evident from the proportions of calcified cartilaginous remnants in the secondary spongiosa (P1. $\mathbf{x} c, d$ ) and, as suggested by Acheson (1959), should probably be regarded not as an increase in the amount of matrix but as evidence of a reduced compression of the cartilaginous strands, due to the smaller size of the maturing cells. Relatively inactive, thin, spindly osteoblasts were found on the short, thick, calcified trabeculae of the primary spongiosa, with less than normal production of osseous tissue ( $\mathrm{Pl}$. I).

The reduced rate of cartilaginous growth and hypertrophy was associated with less longitudinal, but relatively more lateral, deposition of bone. P1. I $d$ shows the lateral linking of the thick calcified cartilage remnants by true bone. Bone resorption in the early stages was as active as in the normal animal and, together with the reduced growth of cartilage and bone, led to destruction of much of the primary spongiosa (P1. I $c, d)$; consequently osteoclasis was found near to the epiphysial cartilage. When immature cartilage obstructed the forward movement of the osteoclasts, they appeared to move parallel to the surface of the cartilage, thereby separating the trabeculae of calcified cartilage from the epiphysial plate (Pl. $2 h$; pig no. 50 ). Separation of calcified cartilage columns by osteoclasis and the lateral linking of the remnants by bone gave rise to the structures revealed by radiography (p.488) as transverse trabeculae.

The continued imbalance between deposition and absorption of bone was associated with increased osteoporosis; bony trabeculae became fewer and calcified cartilaginous trabeculae shorter until, in severely affected animals, the surface of the cartilage often showed bony plugs which sealed the ends of the columns of proliferating cells. Ultimately these bony plugs may fuse; where fusion occurred there were no mature cartilage cells or primary spongiosa and the epiphysial cartilage was covered by a thin, usually incomplete, layer of bone. This is probably the 'sealing off' process described by Frandsen, Nelson, Sulon, Becks \& Evans (1954) and by Park \& Richter (I953).

None of the protein-calorie deficient pigs showed any signs of rickets, nor was there any excess osteoid tissue, although osteocytes were not always as fully compressed as 
in the bones of normal animals. Deposition of periosteal bone, reorganization of the 'funnel' region and development of the Haversian system were all seriously retarded. In the malnourished animals the marrow was oedematous and almost cell-free.

The effects of the different diets could be modified by alterations in the experimental test period: thus pig no. 93 received the $\mathrm{LP}+\mathrm{CH}$ diet for 53 days and the bones showed moderately severe changes, but when the LP diet was given for 190 days (pig no. 32) the changes were much more severe, with complete cessation of cartilage growth, bone deposition and resorption.

\section{Composition of femurs}

When litter-mates were maintained for equal periods on different regimens, the bones with the higher ash content were found (Table 4 ) in the pigs on those regimens having the highest protein values (Platt et al. I96r). For instance, in the experiment

Table 4. Ash content and $\mathrm{A}: \mathrm{R}$ ratios of the bones

\begin{tabular}{|c|c|c|c|c|c|}
\hline Pig no. & $\begin{array}{l}\text { Age at death } \\
\text { (days) }\end{array}$ & $\begin{array}{l}\text { Duration of } \\
\text { experiment } \\
\text { (days) }\end{array}$ & Diet* & $\begin{array}{c}\text { Total ash } \\
\text { content } \\
\text { (g) }\end{array}$ & $\begin{array}{l}A: R \text { ratio } \\
\text { of shaft } \dagger\end{array}$ \\
\hline 96 & 66 & 55 & ${ }_{5} \mathrm{CLP}$ ad lib. & $7 \cdot 13$ & $r \cdot 6 r$ \\
\hline 88 & 66 & 55 & 5 CLP & $4 \cdot 97$ & $r \cdot 60$ \\
\hline 92 & 63 & 52 & LP & $2 \cdot 75$ & $r \cdot 63$ \\
\hline 93 & 64 & 53 & $\mathrm{LP}+\mathrm{CH}$ & 2.53 & $1 \cdot 6 \mathrm{I}$ \\
\hline 72 & 165 & $\mathrm{I}_{42}$ & ${ }_{5} \mathrm{CLP}+\mathrm{V}$ & 10.5 & $I \cdot 84$ \\
\hline 74 & 166 & I43 & $L P+V$ & $6 \cdot 32$ & $\mathrm{I} \cdot 8 \mathrm{r}$ \\
\hline $7 \mathrm{I}$ & 166 & I 43 & $\mathrm{LP}+\mathrm{CH}+\mathrm{V}$ & $3 \cdot 75$ & $I \cdot 9 I$ \\
\hline 103 & I I & - & N1 & $2 \cdot 33$ & $r \cdot 3 r$ \\
\hline 105 & 20 & - & $\mathrm{N} 1$ & $4 \cdot 44$ & $I \cdot 34$ \\
\hline 99 & 26 & - & $\mathrm{Nl}$ & $5 \cdot 36$ & $\mathrm{I} \cdot 43$ \\
\hline 98 & 41 & - & $\mathrm{Nl}$ & 10.19 & $1 \cdot 47$ \\
\hline 106 & 56 & - & Nl & $2 \pi \cdot 48$ & I.59 \\
\hline 100 & 64 & - & N1 & $28 \cdot 28$ & $1 \cdot 72$ \\
\hline 90 & 65 & - & N1 & $21 \cdot 9$ & 1.85 \\
\hline 104 & $8 I$ & - & Nl & $42 \cdot 9$ & I. 76 \\
\hline 102 & 90 & - & N1 & $47 \cdot 48$ & $\mathrm{I} \cdot 68$ \\
\hline
\end{tabular}

* See Table I; Nl, normal.

† See p. 486. Epiphysis, articular and growth cartilage not included.

lasting 52-55 days, the femur of pig no. 88 on the ${ }_{5}$ CLP diet had an ash content of $4.97 \mathrm{~g}$; that of pig no. 92 on the LP diet had only $2 \cdot 75 \mathrm{~g}$ ash, although the vitamin, mineral and calorie intakes of both these animals were substantially the same (see Table 2). By giving extra carbohydrate (pig no. 93, $\mathrm{LP}+\mathrm{CH}$ ) a bone with an even lower ash content $(2 \cdot 53 \mathrm{~g})$ was found. Similar differences were observed between bones having higher total ash contents in the experiment lasting ${ }^{42-143}$ days (pigs nos. 72 , 74 and $7 \mathrm{I}$ ), in which the animals were given diets that contained extra $B$ vitamins and calcium $\left(650 \mathrm{mg} /\right.$ day as $\left.\mathrm{CaCO}_{3}\right)$. The $A: R$ ratios of the shafts of the femurs were similar for each age group ( $\mathrm{I} \cdot 6$ for the younger and $\mathrm{I} \cdot 8$ for the older pigs) despite wide differences in the total ash content (Table 4). There appears, then, to be no impairment of mineralization of such matrix as is laid down: when osteoporosis occurs it must therefore be due to insufficient formation of the matrix. 


\section{Bones of the skull and vertebral column}

Changes similar to those described above (p. 489) were found in the cartilage at the base of the skull; they could be correlated with the degree of protein-calorie deficiency (Table 2). The occipital, sphenoid and ethmoid bones of the pigs given the LP or LP + CH diets were osteoporotic, whereas those of the animals on the 5 CLP diet were more nearly normal. The mandibles of the protein-calorie deficient animals were small, but the teeth were only slightly smaller than the normal. Consequently the teeth, especially the unerupted molars, were crowded.

The bones of the vertebral column were small and osteoporotic; the effect of diet on the size of the second cervical vertebra and on the area of the cross-section of its canal are shown in Pl. $2 e-g$. The bone of the animal on the LP diet was much smaller than that of a normal litter-mate of the same age (6r-63 days), being similar in size to that of a younger normal animal ( 33 days). The area of the cross-section of the vertebral canal was $16-17 \%$ of the total area of the cross-section of the normal vertebras; however, in the animal on the LP diet it constituted a relatively larger proportion, $21 \%$, of the whole. Abnormalities have already been reported in the central nervous systems of malnourished pigs (Platt \& Stewart, I960; Meyer, Stewart \& Platt, I96I) and further investigation is needed to elucidate the part that may be played by disparity in the rates of growth of bone and nervous tissue.

\section{DISCUSSION}

Early work on the effect of malnutrition on the skeleton has been well reviewed by Jackson (1925, I929a, $b$ ), who distinguished between total or quantitative inanition, including general underfeeding, and partial or qualitative inanition, including the complete or incomplete absence of proteins, fats, carbohydrates, salts, vitamins or water. However, since the protein value to a consumer of a diet varies with the energy value of the amount eaten in relation to the consumer's needs (Platt et al. 1961), protein deficiency will occur as a result of underfeeding as well as from a diet deficient in protein. The addition of carbohydrate to a diet low in protein value accentuates the effects on bones attributable to protein deficiency. On the other hand, the addition of carbohydrate to a diet of high protein value given in severely restricted amounts would be expected to enhance its protein value to the consumer.

The severity of the bone disorders described not only varied with the protein value of the diet but also with the duration of the deficiency of protein and with the age at which the experimental diets were first given. In a recent experiment (unpublished) in which larger animals weighing $6 \mathrm{~kg}$ were used, the differences in bone growth between animals given the LP and LP $+\mathrm{CH}$ diets were small. Disorders were most readily produced when growth, although greatly reduced, had not ceased, for cessation of growth led to severe osteoporosis and the production of a bony plate on the metaphysial surface of the epiphysial cartilage (Frandsen et al. 1954; Park \& Richter, I953; Higginson, 1954).

In the routine care of laboratory animals changes occur, mainly at weekends, which 
are reported to have an effect on behaviour (Lane-Petter, 1953); these might be regarded as emotional in character. The occurrence of radio-opaque lines in the bones of some children have been correlated with emotional upsets (Sontag \& Comstock, 1938). If the psychological factors inherent in a disturbed routine were solely responsible, then a regular weekly cycle of transverse trabeculae would be expected in the bones of all the pigs; however they were seen with varying frequency and only in protein-calorie deficient animals.

Follis (1951) demonstrated in rats after dosing with cortisone a reduction in the proliferation and hypertrophy of cartilage cells. Jesserer \& Kotzaurek (1959) and Stein \& Beller ( 1960 ) believe osteoporosis to be due to a relative excess of glucocorticoids, and many workers (see Asling \& Evans, 1956) have shown that after hypophysectomy or thyroidectomy, endochondral growth ceases. Pigs given the LP or $\mathrm{LP}+\mathrm{CH}$ diets developed abnormalities in the endocrine glands (Godwin \& Platt, 1960; Platt \& Stewart, 1962; Stewart \& Heard, 1959) and in their response to insulin and glucose given intravenously (Heard \& Stewart, 1960). Platt (1959) has drawn attention to the probable relationship of endocrine disorders to the development of transverse trabeculae in bones, and endocrine imbalance may be the explanation of the alternate bands of immature and more mature cartilage, reported by Pratt \& McCance (I960) in the bones of cockerels given insufficient amounts of a normal diet. No such bands were found in the bones of pigs given the $\mathrm{LP}$ or $\mathrm{LP}+\mathrm{CH}$ diets.

Bones showing 'arrested growth lines' (a term which probably includes transverse trabeculae) are common in children in areas where malnutrition is rife (Eliot \& Jackson, 1933; Trowell, Davies \& Dean, 1954), and it has been suggested that such lines are due to periods of dietary shortage separated by periods of plenty (Trowell et al. 1954). Dreizen et al. (1956) investigated the persistence of metaphysial transverse lines or 'scars' in groups of children with and without 'nutritional failure' and found that, although the total number of 'scars' (complete lines), together with what are called 'remnants' (said to be partially resorbed lines), was equal in the two groups, the number of 'scars' or unresorbed lines was greater in the group with 'nutritional failure'. They suggested that this was due to reduced metaphysial reorganization. The histological changes in the ribs of children suffering from kwashiorkor, described by Higginson (1954), are similar to those found in the radii of the protein-calorie deficient pigs. His illustration (p. 393) also shows the lateral fusions and lack of continuity of the longitudinal trabeculae which are such prominent features in the bones of the malnourished pigs. Walker \& Arvidsson (1954) analysed the dry fat-free ribs from the subjects investigated by Higginson; they found that the percentage of ash was within the normal range, but that the total mineral content was seriously reduced.

Although the bones of the malnourished pigs showed no evidence of rickets, there were changes in endochondral growth, in some respects similar to those described by Wolbach (1946) in rats and attributed by him to a deficiency of vitamin A. Pigs given the $\mathrm{LP}$ or $\mathrm{LP}+\mathrm{CH}$ diets had abnormally low concentrations of vitamin $\mathrm{A}$ in the blood, but it was never absent (Friend, Heard, Platt, Stewart \& Turner, 1960, 1961). Pigs growing normally require a daily ration containing $25^{\circ} \mathrm{mg} \mathrm{Ca}$ and ${ }_{5} 5^{\circ} \mathrm{mg} \mathrm{P}$ for each 
$\mathrm{kg}$ body-weight (Albritton, 1954). In the experiment here described, pigs were given the same amount of a ration each day (Table 2); the nutrient content, expressed per $\mathrm{kg}$ body-weight, fell therefore as the weight of the animal increased. Pigs on the LP diet grew at very reduced rates and received between 380 and $230 \mathrm{mg} \mathrm{Ca}$ and between 370 and $223 \mathrm{mg} P$ per $\mathrm{kg}$ body-weight. It should be emphasized that the animals on the 5 CLP diet received the same total amounts of $\mathrm{Ca}$ and $\mathrm{P}$, but because of their faster rate of growth were receiving at the end of the experiment only $50-70 \%$ of the normal requirement of $\mathrm{Ca}$ for each $\mathrm{kg}$ body-weight. It is probable that the low-protein diets depressed $\mathrm{Ca}$ absorption (McCance, Widdowson \& Lehmann, 1942; Mellander, 1955), and the Ca content of the blood, in agreement with Linneweh (1939), was found to be reduced in the protein-depleted animals (unpublished).

Nordin (1960) has shown that in man calcium therapy arrests the progress of senile osteoporosis, but has failed to demonstrate any improvement radiologically. The osteoporosis in pigs, brought about by the protein-calorie deficient diets, could not be corrected by the addition of calcium (Pl. $2 b, c$ ), whereas the replacement of carbohydrate by protein, without extra $\mathrm{Ca}$, produced a considerable increase in bone ash and a less osteoporotic bone (Table 4 ; Pl. 2a,b), suggesting that in the prevention or treatment of osteoporosis an increase in the protein value of the diet may be as important as, or more important than, supplementation with $\mathrm{Ca}$.

Harris (193 $a, b$ ), describing arrested growth lines in bone, showed that they might vary from a well-marked line after an acute illness to an incomplete line of arrested growth with a lack of cartilage proliferation. Platt ( $196 \mathrm{r}$ ) has suggested that, when a line is produced in bone after a severe illness, it may be the result of protein deficiency; for illness increases the body's need for protein at a time when intake is unlikely to rise and may well fall. Calorie restriction has been shown by Platt et al. (1961) to cause a disproportionately large fall in the protein value of the diet; it follows therefore that, when loss of appetite or malabsorption occurs, the protein value of the diet to the consumer is reduced, and retardation of bone growth and the osteoporosis of proteincalorie deficiency may occur. The transverse lines described in the pig bones beara striking resemblance to those in the bone of a chronically infected patient (Harris, $193 \mathrm{I} b$, Fig. $3 \mathrm{I}$ ), and it is probable that they are manifestations of the same basic change.

\section{S U M M ARY}

I. A study was made of the growth in length, the radiological and histological appearances and mineral content of the bones of young pigs suffering from proteincalorie deficiency.

2. The growth of the long bones was slow; there was a generalized rarefaction of the bone, and radio-opaque transverse trabeculae developed in the metaphyses.

3. Histologically the changes were related to a reduced rate of proliferation and maturation of the cartilage and a reduction in osteoblastic activity; osteoclasis was less severely affected. No excess osteoid tissue was present.

4. The ash content of the bones was low, but the ratio of ash to bone matrix ( $A: R$ ratio) was not affected by the protein value to the consumer of the dietary regimens. 
5. The rate of growth in length and the radiological appearance of the bone were improved by replacing part of the carbohydrate of the low-protein diet by an isocaloric amount of protein. The addition of extra calcium to the low-protein diets had no significant effect on bones.

6. The skull bones were small. The size of the lower teeth was only slightly reduced as compared with the reduction in the size of the mandible, thus leading to crowding of the teeth, especially of the unerupted molars.

7. The vertebras were osteoporotic and small; the area of the cross-section of the vertebral canal (e.g. at second cervical region), though smaller than in normal pigs of equal age, was larger than that of vertebras of about the same external dimensions from younger, normal pigs.

8. The occurrence of radio-opaque lines, arrested growth lines or, sometimes, transverse trabeculae, has been described in human subjects. They have been attributed to infections or to endocrine disturbances; it is suggested that the pathological process is basically similar to that produced by us in protein-calorie deficiency.

We are indebted to the Food Research Department, Unilever Ltd, who kindly supplied the pigs used in these experiments. We acknowledge with gratitude the help of our colleagues, in particular that of Mr R. Preece and Mr P. Ward in the preparation of photomicrographs, radiographs and histological specimens, and of Mrs M. Kelley in the preparation of the manuscript.

\section{REFERENCES}

Acheson, R. M. (1959). F. Anat., Lond., 93, 123.

Albritton, E. C. (editor) (1954). Standard Values in Nutrition and Metabolism. Philadelphia and London: W. B. Saunders Co.

Asling, C. W. \& Evans, H. M. (1956). In The Biochemistry and Physiology of Bone, p. 67x. [G. H. Bourne, editor.] New York: Academic Press Inc.

Braude, R., Foot, A. S., Henry, K. M., Kon, S. K., Thompson, S. Y. \& Mead, T. H. (1941). Biochem. F. 35, 693 .

Chick, H., Korenchevsky, V. \& Roscoe, M. H. (1926). Biochem. F. 20, 622.

Chick, H. \& Roscoe, M. H. (1926). Biochem. F. 20, 137.

de Loureiro, J. A. (193 I). Arch. pat., Lisboa, 3, 72.

Dreizen, S., Currie, C., Gilley, E. J. \& Spies, T. D. (1956). Amer. F. Roentgenol. 76, 482.

Eliot, M. M. \& Jackson, E. B. (1933). Amer. F. Dis. Child. 46, 2237.

Eliot, M. M., Souther, S. P. \& Park, E. A. (1927). Fohns Hopk. Hosp. Bull. 41, 364 .

FAO (1957). F.A.O. nutr. Stud. no. 15.

Follis, R. H. Jr. (195I). Proc. Soc. exp. Biol., N.Y., 76, 722.

Follis, R. H. Jr. \& Park, E. A. (1952). Amer. F. Roentgenol. 68, 709.

Frandsen, A. M., Nelson, M. M., Sulon, E., Becks, H. \& Evans, H. M. (1954). Anat. Rec. Ir9, 247.

Friend, C. J., Heard, C. R. C., Platt, B. S., Stewart, R. J. C. \& Turner, M. R. (1960). Proc. Nutr. Soc. 19, xxxiv.

Friend, C. J., Heard, C. R. C., Platt, B. S., Stewart, R. J. C. \& Turner, M. R. (1961). Brit. F. Nutr. 15, 231.

Godwin, K. O. \& Platt, B. S. (1960). Proc. Nutr. Soc. r9, x.

Harris, H. A. (1924-5). F. Anat., Lond., 59, P. 94.

Harris, H. A. (1926). Arch. intern. Med. 38, 785.

Harris, H. A. (1931 a). Brit. F. Radiol. N.S. 4, 56r.

Harris, H. A. (193 I b). Brit. F. Radiol. N.S. 4, 622.

Heard, C. R. C. \& Stewart, R. J. C. (1960). Acta endocr., Copenhagen, Suppl. 51, p. I 277.

Higginson, J. (I 954). Metabolism, 3, 392.

Jackson, C. M. (1925). The Effects of Inanition and Malnutrition upon Growth and Structure. London: J. \& A. Churchill Ltd.

Jackson, C. M. (1929a). Arch. Path. (Lab. Med.), 7, 1042. 


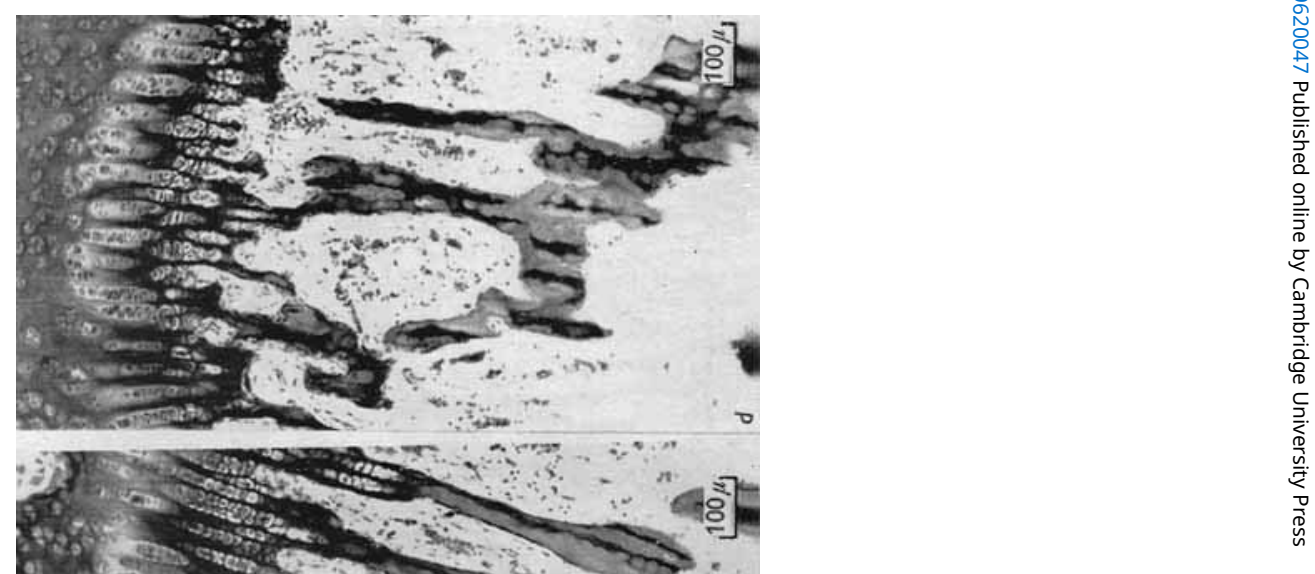


British Fournal of Nutrition, I'ol. 16, No. 4

Plate 2

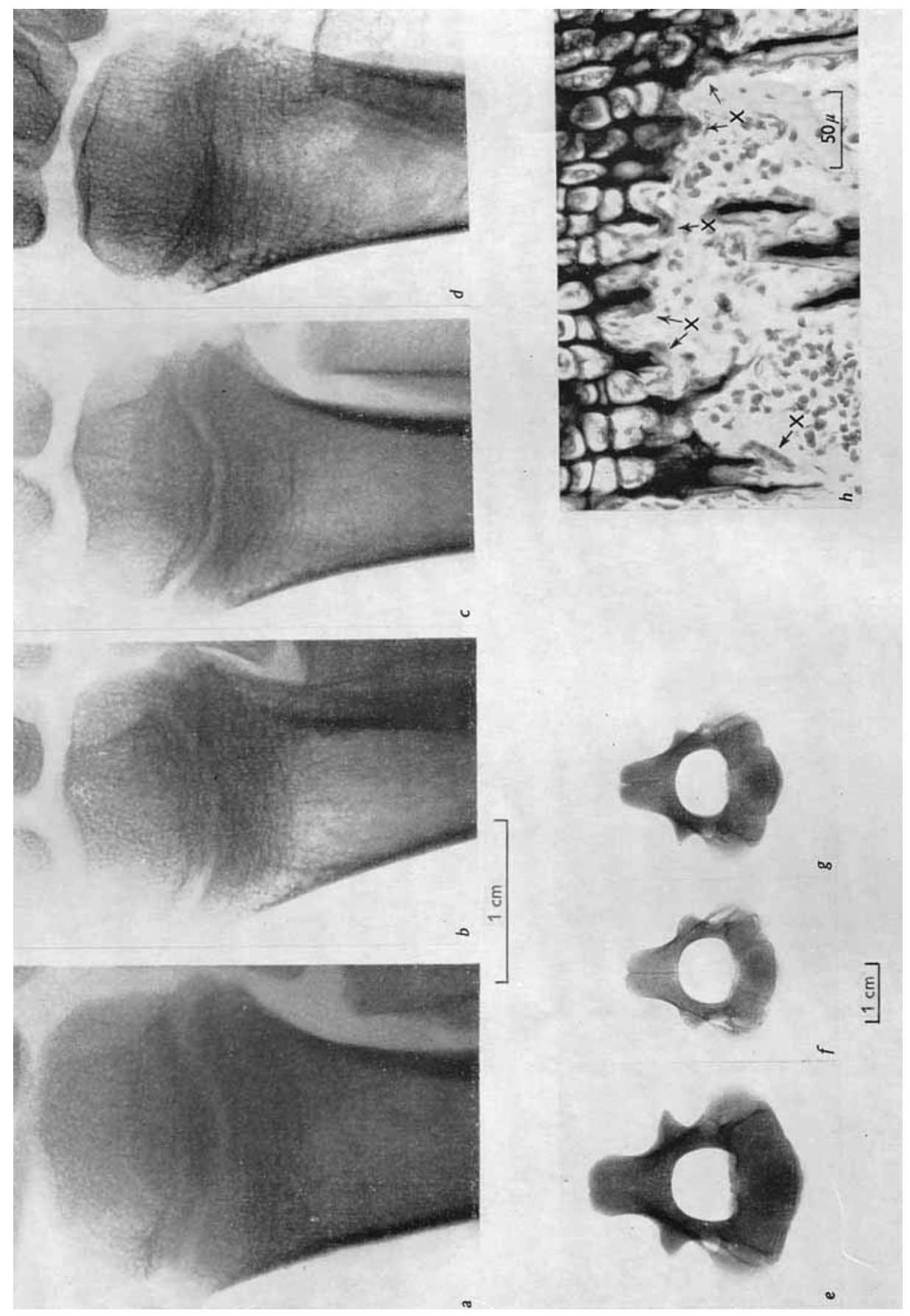

B. S. PIAATI AND R. J. C. S'TEWART' 
Jackson, C. M. (1929b). Arch. Path. (Lab. Med.), 8, 273.

Jesserer, H. \& Kotzaurek, R. (1959). Klin. Wschr. 37, 285.

Joint FAO/WHO Expert Committee on Nutrition (1962). Tech. Rep. Wld Hlth Org. (In the Press.)

Lane-Petter, W. (1953). Brit. F. Anim. Behav. 1, 124.

Linneweh, F. (1939). Klin. Wschr. I8, 350.

McCance, R. A., Ford, E. H. R. \& Brown, W. A. B. (1961). Brit. F. Nutr. 15, 2 13.

McCance, R. A., Widdowson, E. M. \& Lehmann, H. (1942). Biochem. F. 36, 686.

Mellander, O. (1955). Nutr. Rev. 13, 161.

Meyer, A., Stewart, R. J. C. \& Platt, B. S. (196r). Proc. Nutr. Soc. 20, xviii.

Nordin, B. E. C. (1960). Acta endocr., Copenhagen, Suppl. 5I, p. 517.

Orth, J. (1896). Berl. klin. Wschr. 33, 273.

Park, E. A. \& Richter, C. P. (г953). Fohns Hopk. Hosp. Bull. 93, 234.

Platt, B. S. (1959). Trans. R. Soc. trop. Med. Hyg. 52, 189.

Platt, B. S. (1961). Fed. Proc. 20, no. 1, part 3, p. 188.

Platt, B. S. \& Miller, D. S. (1959). Proc. Nutr. Soc. 18, vii.

Platt, B. S., Miller, D. S. \& Payne, P. R. (1961). In Recent Advances in Human Nutrition, p. $35 \mathrm{I}$.

[J. F. Brock, editor.] London: J. \& A. Churchill Ltd.

Platt, B. S. \& Stewart, R. J. C. (1960). Proc. Nutr. Soc. I9, viii.

Platt, B. S. \& Stewart, R. J. C. (1962). Proc. Nutr. Soc. 21, v.

Pratt, C. W. M. \& McCance, R. A. (1960). Brit. $\mathcal{~ f . ~ N u t r . ~ 1 4 , ~} 75$.

Sontag, L. W. (1938). Amer. F. Dis. Child. 55, 1248.

Sontag, L. W. \& Comstock, G. (1938). Amer. F. Dis. Child. 56, 301.

Sontag, L. W. \& Harris, L. M. (1938). Amer. F. Dis. Child. 56, 1248.

Stein, I. \& Beller, M. L. (1960). Acta endocr., Copenhagen, Suppl. 5 I, p. 513.

Stewart, R. J. C. \& Heard, C. R. C. (r959). Proc. Nutr. Soc. r8, x.

Stewart, R. J. C. \& Platt, B. S. (1958). Proc. Nutr. Soc. 17, v.

Stewart, R. J. C. \& Platt, B. S. (196I). Proc. Nutr. Soc. 20, xlvi.

Trowell, H. C., Davies, J. N. P. \& Dean, R. F. A. (1954). Kwashiorkor. London: Edwin Arnold (Publishers) Ltd.

Walker, A. R. P. \& Arvidsson, U. B. (1954). Metabolism, 3, 385.

Wittmaak, K. (I9I I). Verh. dtsch. otol. Ges. 20, 289.

Wolbach, S. B. (1946). Proc. Chicago Inst. Med. 16, I 8.

\section{EXPLANATION OF PLATES}

\section{Plate I}

Photomicrographs of the distal epiphysial cartilages and metaphyses of the radii of pigs given diets with different protein contents.
(a) Pig no. 9o, Ni diet ad lib.
(c) Pig no. 92, LP diet.
(b) Pig no. 88, 5 CLP diet.
(d) Pig no. 93, $\mathrm{LP}+\mathrm{CH}$ diet.

Note. In the bones of the animals given diets with low protein values, the columns of proliferating and maturing cartilage cells are short and the individual cells small, there are few normally placed primary but many transverse trabeculae and the amount of calcified cartilage within the trabeculae is excessive.

Plate 2

$(a-d)$ Radiographs of distal ends of the radii of pigs with different degrees of protein-calorie deficiency.

(a) Pig no. 76 after I 2 days on the 5 CL.P diet.

(b) Pig no. 77 after I $I 2$ days on the LP diet.

(c) Pig no. 74 after II 2 days on the LP $+\mathrm{V}$ diet.

Note the smaller size, lower density and more numerous transverse trabeculae of $(b, c, d)$ compared with (a); the addition to the diet of a mixture of $\mathrm{B}$ vitamins and calcium $(650 \mathrm{mg} /$ day $)$ as $\mathrm{CaCO}_{3}$ did not bring about an increase in bone size or density (cf. $b, c)$.

$(e-g)$ Radiographs of the second cervical vertebras.

(e) Pig no. 63, N1 diet, aged 63 days.

(f) Pig no. 6r, LP diet, aged 6r days.

(g) Pig no. 40, Nl diet, aged 33 days.

Note the smaller overall size of $(f)$ compared with $(e)$ and the similarity in overall size of $(f)$ and the bone of the younger, normal animal. The area of the cross-section of the vertebral canal forms $2 \mathrm{I} \%$ of the whole cross-section of $(f)$ compared with only $16-17 \%$ in $(g)$ and $(e)$.

(h) Photomicrograph of the distal epiphysial cartilage of the radius of pig no. $5 \circ$ given the LP diet for 57 days. Note osteoclasts $(x)$ separating primary trabeculae from the epiphysial cartilage. 